\title{
ZRÓWNOWAŻONY ROZWÓJ JAKO STRATEGIA DEFINIUJĄCA NOWOCZESNE GOSPODAROWANIE PRZESTRZENIĄ W POLSCE (ASPEKTY PRAWNE)
}

\begin{abstract}
WSTĘP
Początków idei zrównoważonego rozwoju należy szukać w prawie międzynarodowym. Po raz pierwszy posłużono się tym pojęciem na Światowej Konferencji ONZ, która odbyła się w Sztokholmie w dniach 5-16 czerwca 1972 r. z udziałem przedstawicieli państw, organizacji międzynarodowych i obserwatorów z organizacji pozarządowych, głównie ekologicznych ${ }^{1}$. Owocem konferencji była Deklaracja w sprawie środowiska człowieka z 1972 r., zwana Deklaracją Sztokholmską ${ }^{2}$, w której przyjęto 26 zasad międzynarodowego prawa ochrony środowiska. Zasady te nie miały mocy wiążącej, jednak sama Deklaracja Sztokholmska stworzyła silne podwaliny dla rozwoju międzynarodowego prawa środowiska, służąc jako zbiór uniwersalnych standardów dla umów międzynarodowych oraz dla krajowych systemów prawnej ochrony środowiska. Kolejny przełom nastąpił w 1983 r., kiedy Światowa Komisja do spraw Środowiska i Rozwoju powołana przez Zgromadzenie Ogólne ONZ w raporcie końcowym zdefiniowała pojęcie zrów-

\footnotetext{
Zagadnienie równorzędnego traktowania środowiska i gospodarki pojawiło się jednak wcześniej - w rezolucji uchwalonej na XXIII Sesji Zgromadzenia Ogólnego ONZ dnia 3 grudnia 1968 roku. Wygłoszony w dniu 23 maja 1969 r. raport Sekretarza Generalnego pt. „Człowiek i jego środowisko" miał bezprecedensowe znaczenie w upowszechnianiu idei ochrony środowiska na całym świecie, rok 1968 uznaje się zaś powszechnie za datę narodzin międzynarodowego prawa ochrony środowiska, zob. szerzej na ten temat, R. Paczuski, Zaczęto się w ONZ. Zrórwnoważony rozwój zadaniem wspótczesnego państwa - rola polityki i prawa w jego realizacji, „Ekoprofit” 1998, nr 7/8, s. 30 .

Wybór dokumentów do nauki prawa międzynarodowego, red. K. Kokot, K. Wolfke, wyd. III, Wrocław 1976, s. 55-116.
} 
noważonego rozwoju ${ }^{3}$. Koncepcja ta została rozwinięta w na konferencji ONZ „Środowisko i Rozwój”- UNCED (United Nations Conference on Environment and Development), która odbyła się w dniach 3-14 czerwca 1992 r. w Rio de Janeiro. W swym założeniu Konferencja w Rio, nawiązywała wprost do Konferencji Sztokholmskiej i była jej kontynuacją, a ponieważ nie udało się wcielić w życie wielu ambitnych zamierzeń tej ostatniej, uczestnicy konferencji w Rio nawiązując do zasad Deklaracji Sztokholmskiej, postanowili skoncentrować się na postawionym w niej haśle zrównoważonego rozwoju ${ }^{4}$.

W jednym z pięciu dokumentów przyjętych na tej konferencji ${ }^{5}$, Deklaracji z Rio de Janeiro, sformułowano 27 zasad zrównoważonego rozwoju, których podstawowym przesłaniem jest niemożliwość traktowania ochrony środowiska i gospodarki jako dziedzin ze sobą niepowiązanych. We wszystkich dokumentach Konferencji z Rio przewijała się podstawowa teza sformułowana już wcześniej przez Komisję ONZ ds. Środowiska i Rozwoju, która głosiła, że gospodarka światowa musi zaspokajać potrzeby ludzkości i jej uzasadnione wymagania, ale ich wzrost powinien mieścić się w granicach ekologicznej pojemności naszej planety. Teza ta stała się punktem wyjścia i podstawą dla sformułowania zasady trwałego i zrównoważonego rozwoju. Nie tracąc z pola widzenia długiej listy podstawowych potrzeb ochrony środowiska, 10 lat po Konferencji w Rio de Janeiro, w dniach od 26 sierpnia do 4 września 2002 r. w Johannesburgu odbyła się trzecia ekologiczna światowa konferencja ONZ. Jej główne postulaty to m.in. wyrównanie szans rozwojowych przez znaczącą redukcję liczby głodujących, poprawa stanu sanitarnego zaniedbanych środowisk i zaopatrzenia ich w wodę, poprawa dostępu do źródeł energii zwłaszcza zaś źródeł energii odnawialnej itp.

3 Głównym założeniem tej definicji było, że rozwój gospodarczy nie powinien odbywać się kosztem zasobów nieodnawialnych albo kosztem zużycia zasobów odnawialnych w tempie przekraczającym tempo ich naturalnej odnowy, zob. J. Ciechanowicz, Międzynarodowe prawo ochrony środowiska, Wydawnictwa Prawnicze PWN, Warszawa 1999, s. 61.

4 J. Machowski, Ochrona środowiska. Prawo i zrównoważony rozwój, Warszawa 2003, s. 27.

$\mathrm{Na}$ Konferencji przyjęto następujące dokumenty: Deklarację z Rio, Globalny Program Działań Agenda 21, Deklarację o ochronie lasów, oraz podpisano dwie Konwencje o znaczeniu światowym: Konwencję o różnorodności biologicznej i Konwencję o ochronie klimatu. Warto podkreślić, że wymienione deklaracje należą do tzw. miękkiego prawa środowiska- soft law. Składają się nań uchwały organizacji międzynarodowych i ich organów, deklaracje międzyrządowe oraz akty końcowe konferencji. Chociaż nie mają mocy wiążącej, to dokumenty te nie są pozbawione znaczenia prawnego. Odgrywają bowiem ważną rolę w procesie tworzenia przyszłego prawa - twardego (hard law), czyli umów międzynarodowych, i wpływają na rozwój międzynarodowego prawa środowiska, zob. G. Grabowska, Cztowiek i środowisko w prawie międzynarodowym, „Państwo i Prawo” 1996, z. 1, s. 27; eadm, Europejskie prawo środowiska, PWN, Warszawa 2001, s. 97-88; K. Wolfke, Zagadnienie źódet w międzynarodowym prawie środowiska, Acta Universitatis Brunensis - Iuridica nr 29, s. 107-109; S. Skubiszewski, Uchwaty prawotwórcze organizacji międzynarodowych. Przegląd zagadnienia i analiza wstępna, Poznań 1965. 
Zasada zrównoważonego rozwoju, będąca myślą przewodnią największych konferencji ekologicznych stała się podstawą całego systemu międzynarodowego prawa środowiska. Wypada wspomnieć, że znalazła ona wyraz w prawie europejskim, choć ochrona środowiska nie od początku należała do priorytetowych dziedzin działalności tej organizacji ${ }^{6}$. Podstawę traktatową ochrona środowiska zyskała dopiero 17 lutego 1986 r. w Jednolitym Akcie Europejskim, który jako nowelizacja Traktatu rzymskiego wprowadził rozdział "Środowisko naturalne”. Postanowienia tego aktu zostały następnie wzmocnione w Traktacie o Unii Europejskiej z 7 lutego 1992 r. z Maastricht, który stał się punktem zwrotnym, wprowadzając do jej systemu prawnego nową jakość opartą na zasadzie zrównoważonego rozwoju.

Oprócz aktów prawa pierwotnego, a także ogromnej liczby aktów prawa pochodnego w tym przedmiocie (głównie dyrektyw, rozporządzeń, decyzji) państwa - członkowie Unii Europejskiej, kierują się programami działań w przedmiocie ochrony środowiska i zrównoważonego rozwoju przyjmowanymi od początku lat 70. XX w. w formie uchwał organów Unii ${ }^{7}$. Choć nie stanowią one norm prawnie wiążących, to zawarte $w$ nich wytyczne dla polityki (w tym legislacyjnej) zobowiązują władze poszczególnych państw do zgodnego z nimi postępowania.

\section{POJĘCIE ZRÓWNOWAŻONEGO ROZWOJU}

Zrównoważony rozwój to polski odpowiednik angielskiego terminu sustainable development, który w zasadzie nie jest bezpośrednio przetłumaczalny na język polski. W literaturze spotyka się takie określenia, jak: rozwój trwały, roz-

6 W prawie pierwotnym Unii Europejskiej przez 30 lat brakowało wyraźnych postanowień dotyczących ochrony środowiska, zob. K. Równy, Ekologiczne warunki członkostwa w Unii Europejskiej $i$ zbliżanie się do nich w Polsce, cz. I: Podstawy wymogów ekologicznych w prawie wspólnotowym, „Prawo i Środowisko” 1997, nr 3, s. 14. Traktat rzymski z 25 marca 1957 r., ustanawiający EWG, problematykę ochrony europejskiego środowiska traktował wąsko i marginesowo. $Z$ biegiem czasu zaczęto dostrzegać transgraniczny charakter zjawisk środowiskowych. Dopiero jednak rok 1972 uważa się za początek celowych działań Wspólnoty na rzecz ochrony środowiska - początek jej polityki środowiskowej, zob. szerzej na ten temat, Nowe regulacje prawne ochrony środowiska w Polsce dostosowanie do wymagań Unii Europejskiej, red. J. Jendrośka, Centrum Prawa Ekologicznego, Wrocław 2001, s. 8.

7 Szerzej na ten temat, zob. K. Gruszecki, Ochrona prawna środowiska w Unii Europejskiejźódta prawa europejskiego, „Aura” 1999, nr 1, s. 7-8.

${ }_{8}$ Stowo wstępne, [do:] Dokumenty końcowe Konferencji Narodów Zjednoczonych „Środowisko i Rozwój”, Rio de Janeiro, 3-14 czerwca 1992, „Szczyt Ziemi”, Warszawa 1993, s. 9-10. 
wój zrównoważony ${ }^{9}$, ekorozwój ${ }^{10}$, rozwój ciągły ${ }^{11}$, rozwój zintegrowany ${ }^{12}$, a także zrównoważony wzrost ${ }^{13}$ i wzrost samopodtrzymujący się (permanentny) ${ }^{14}$. Niezależnie jednak od przyjętego tłumaczenia terminem tym określa się pewien model rozwoju gospodarczego dający się pogodzić $\mathrm{z}$ wymogami ochrony środowiska, zaspokajający nie tylko konsumpcyjne potrzeby ludzi, ale i ich prawo do życia w czystym środowisku.

Istotą zrównoważonego rozwoju jest równorzędne traktowanie racji społecznych, ekonomicznych i ekologicznych, co oznacza konieczność integrowania problematyki ochrony środowiska $\mathrm{z}$ polityką w poszczególnych działach gospodarki. Akceptując takie podejście do środowiska i rozwoju, państwa powinny wypracować odpowiednie mechanizmy prawne umożliwiające jej wprowadzenie w życie ${ }^{15}$.

Wdrożenie tej zasady do systemów prawnych państw ma zapewnić realizację czterech podstawowych celów: ekologicznych (powstrzymanie degradacji środowiska i eliminacja jego dalszych zagrożeń), ekonomicznych (zaspokajanie podstawowych potrzeb materialnych człowieka, rozwój gospodarczy osiągany z uwzględnieniem technik i technologii przyjaznych środowisku) oraz humanitarnych i społecznych (likwidacja nędzy, głodu, ochrona zdrowia i życia) ${ }^{16}$.

Zrównoważony rozwój, pozostając zasadą, przekształca się stopniowo w dyscyplinę naukową, nowoczesny kierunek rozwoju gospodarki ${ }^{17}$. Podmioty go-

9 Zob. R. Paczuski, Prawo ocbrony środowiska, Bydgoszcz 2000, s. 35; J. Boć, K. Nowacki, E. Samborska-Boć, Ochrona środowiska, Kolonia Limited, Wrocław 2000, s. 60.

10 Zob. B. Poskrobko, Teoretyczne aspekty ekorozwoju, „Ekonomia i Środowisko” 1997, nr 1, s. 7 i n.; S. Kozłowski, Droga do ekorozwoju, Warszawa 1994.

11 Zob. M.M. Kenig-Witkowska, Koncepcja „sustainable development” w prawie międzynarodowym, „Państwo i Prawo” 1988, z. 8, s. 45 i n. Zdaniem autorki określenie sustainable development jako ekorozwoju lub rozwoju zrównoważonego jest niefortunne i źle oddaje istotę problemu. Odmienny pogląd prezentuje M. Sitek, której zdaniem termin sustainable development powinien być tłumaczony jako „rozwój zrównoważony”, argumentując to m.in. art. 5 Konstytucji, zob. M. Sitek, „Sustainable development” - ciagty czy zrórwnoważony rozwój ?, artykuł polemiczny, „Państwo i Prawo” 1999 , z. 2, s. 82-83.

12 A. Chmielak, Problemy badawcze teorii trwatego i zrównoważonego rozwoju, „Ekonomia i Środowisko" 1998, nr 2, s. 35.

13 A. Budnikowski, Dostosowanie polityki ochrony środowiska w Polsce do wymogów Unii Europejskiej, SGH, Warszawa 1997, s. 5.

14 Takie określenie pojawiło się pod koniec lat 80.w teorii ekonomii i polityce gospodarczej, zob. J. Boć, K. Nowacki, E. Samborska-Boć, op. cit., s. 60.

15 G. Grabowska, Europejskie prawo, s. 197.

16 Zob. B. Poskrobko, Spoteczne czynniki ochrony środowiska, [w:] Ochrona środowiska. Problemy spoteczne, ekonomiczne i prawne, Warszawa 1998, s. 12; M.M. Kenig-Witkowska, op. cit., s. 45; D. Pyć, Zasada zrównoważonego rozwoju w prawie międzynarodowym. Materiały z konferencji pt. Prawo międzynarodowe w dobie transformacji społeczności międzynarodowej, Kraków 21-22 września 2000 r.

17 Możliwość traktowania zrównoważonego rozwoju jako dyscypliny naukowej dostrzega B. Poskrobko, Teoretyczne aspekty, s. 8-9. Autor przedstawia te relacje obrazowo za pomocą trzech 
spodarcze coraz częściej angażują się w działania na rzecz ochrony środowiska, uczestnicząc w ten sposób w praktycznej realizacji tej zasady ${ }^{18}$. Koncepcja ta wymaga jednak przyjęcia przez państwa nowych sposobów organizacji gospodarki w skali kraju, regionu i samorządu terytorialnego. Jednym z obszarów, na których państwo i jego struktury powinny realizować omawianą zasadę, jest gospodarka przestrzenna. Pojęciem i ideą zrównoważonego rozwoju zajmuje się wiele dziedzin nauki ${ }^{19}$. Występuje ono w naukach prawnych ${ }^{20} \mathrm{i}$ ekonomicznych, ale również w znacznie węższych dziedzinach nauki, jak np. nauki urbanistyczne.

Punktem przełomowym w posługiwaniu się pojęciem zrównoważonego rozwoju w naukach prawnych było uchwalenie Konstytucji z 2 kwietnia 1997 r. Nieaktualne stały się bowiem inne tłumaczenia na język polski terminu sustainable development $\mathrm{w}$ języku prawnym ${ }^{21}$. Konstytucja RP dokonała jednak o wiele więcej niż tylko uporządkowania terminologicznego, mianowicie zrównoważony rozwój jest odtąd jedną z naczelnych zasad ustroju RP.

\section{KONCEPCJA ZRÓWNOWAŻONEGO ROZWOJU W PRAWIE PLANOWANIA I ZAGOSPODAROWANIA PRZESTRZENNEGO}

Konstytucyjna zasada zrównoważonego rozwoju jest stale konkretyzowana przez ustawodawstwo zwykłe. W celu ustalenia treści zasady zrównoważonego rozwoju szczególna rola przypada ustawie z 27 marca 2003 r. o planowaniu i zagospodarowaniu przestrzennym ${ }^{22}$ (dalej u.p.z.p.). Przepisy dotyczące zagospodarowania przestrzennego jako pierwsze posługiwały się pojęciem „zrównoważony rozwój” jeszcze pod rządami ustawy z dnia 7 lipca 1994 roku o zagospodarowaniu przestrzennym ${ }^{23}$. W miarę rozwoju prawa zagospodarowania przestrzennego wyod-

okręgów, z których jeden symbolizuje społeczeństwo, drugi gospodarkę, a trzeci środowisko. Eliminacja jednego $z$ tych okręgów - podsystemów (np. środowiska z powodu nadmiernej degradacji) powoduje rozpad dwóch pozostałych.

18 R. Alberski, A. Lisicka, J. Sommer, Polityka ochrony środowiska, Acta Universitatis Wratislaviensis, nr 2406, Wrocław 2002, s. 30.

19 J. Boć, Ochrona środowiska w postanowieniach Konstytucji Rzeczypospolitej Polskiej [w:] Problemy prawa angielskiego i europejskiego oraz reformy w Europie Środkowej (Polska, Wegry), red. K. Nowacki, Acta Uniwersistatis Wratislaviensis, nr 2244, Prawo CCLXXII, Wrocław 2000, s. 190.

20 Odnotować należy, że idea zrównoważonego rozwoju i jej miejsce w systemie prawnym doczekały się kompleksowej publikacji, zob. Z. Bukowski, Zrównoważony rozwój w systemie prawa, Toruń 2009.

21 Zob. K. Równy, Koncepcja zrównoważonego rozwoju w prawie wspólnotowym i polskiej rzeczywistości, „Przegląd Prawa Europejskiego” 2000, nr 2, s. 66-67.

22 Dz.U. Nr 80, poz. 717 z późn. zm. Regulacje związane z zagospodarowaniem przestrzennym po raz pierwszy posługiwały się pojęciem „zrównoważony rozwój”.

23 Tekst jedn. Dz. U z 1999 r. Nr 15, poz. 139 z późn. zm. 
rębniał się w nim katalog zasad ogólnych, wśród których na pierwszy plan wysuwa się zasada zrównoważonego rozwoju ${ }^{24}$.

$\mathrm{Na}$ uwagę zasługuje fakt, że zasada ta w u.p.z.p występuje łącznie z zasadą uwzględniania ładu przestrzennego. Tkwi ona u podstaw wszelkich działań organów administracji rządowej i samorządowej, zarówno w zakresie kształtowania polityki przestrzennej, jak i w kwestii ustalania zasad przeznaczania terenów na określone cele, ich zagospodarowania i zabudowy. Wynika to wyraźnie $\mathrm{z}$ art. 1 u.p.z.p., przy czym ustawa ta, formułując definicję zrównoważonego rozwoju, odwołuje się do analogicznej definicji zawartej w ustawie - Prawo ochrony środowiska ${ }^{25}$. Zasady zrównoważonego rozwoju i ochrony środowiska stanowią $\mathrm{w}$ rozumieniu art. 71 tej ustawy podstawę do sporządzania i aktualizacji koncepcji przestrzennego zagospodarowania kraju, planów zagospodarowania przestrzennego województw, studiów uwarunkowań i kierunków zagospodarowania przestrzennego gmin oraz miejscowych planów zagospodarowania przestrzennego ${ }^{26}$.

Zasada zrównoważonego rozwoju i ładu przestrzennego jest zatem podstawą wszelkich działań planistycznych w sprawach przeznaczenia terenów na określone cele oraz ustalania zasad ich zagospodarowania i zabudowy. Oznacza to, że adresatami tej zasady są organy właściwe w sprawach podejmowania rozstrzygnięć planistycznych, czyli naczelne organy administracji rządowej oraz organy administracji samorządowej na poziomie gminy i województwa. Samo zaś pojęcie ładu przestrzennego ma swoją definicję legalną, zgodnie z którą jest to takie ukształtowanie przestrzeni, które tworzy harmonijną całość oraz uwzględnia w uporządkowanych relacjach wszelkie uwarunkowania i wymagania funkcjonalne, społeczno-gospodarcze, środowiskowe, kulturowe oraz kompozycyjno-estetyczne. Definicja ta pochodzi z nauk urbanistycznych i jako taka wymaga dookreślenia i rozumienia znacznie szerszego: jako ład społeczny - gwarantujący wszystkim użytkownikom możliwość korzystania z walorów przestrzeni; ład estetyczny -

24 Potrzeba wyodrębnienia zasad ogólnych w prawie zagospodarowania przestrzennego została dostrzeżona już dość dawno, zob. Z. Leoński, M. Szewczyk, Zasady prawa budowlanego i zagospodarowania przestrzennego, Bydgoszcz-Poznań 2002.

25 W myśl tej definicji za „zrównoważony rozwój” uważa się taki rozwój społeczno-gospodarczy, w którym następuje proces integrowania działań politycznych, gospodarczych i społecznych, z zachowaniem równowagi przyrodniczej oraz trwałości podstawowych procesów przyrodniczych, w celu zagwarantowania możliwości zaspokajania podstawowych potrzeb poszczególnych społeczności lub obywateli zarówno współczesnego pokolenia, jak i przyszłych pokoleń. Ustawa z dnia 27 kwietnia 2001 r., tekst jedn. z dnia 23 stycznia 2008 r. (Dz.U. Nr 25, poz. 150 z późn.zm.).

26 W literaturze podkreśla się, że nakaz uwzględniania zasady zrównoważonego rozwoju zakłada konieczność zachowania równowagi pomiędzy wszystkimi elementami składającymi się na środowisko, w którym bytuje człowiek, aby przy racjonalnym wykorzystaniu potencjału przyrodniczego możliwe było zaspokajanie potrzeb obecnych i przyszłych pokoleń, zob. J. Sommer w: W. Radecki, J. Sommer, W. Szostek, Ustawa o zagospodarowaniu przestrzennym oraz wybrane przepisy wykonawcze. Komentarz, Wrocław 1995, s. 12. 
czyli harmonia otoczenia; ład ekonomiczny - czyli efektywne gospodarczo wykorzystanie przestrzeni oraz jej właściwe funkcjonowanie; ład kulturowy - czyli szacunek do dziedzictwa narodowego oraz ład ekologiczny - honorujący w możliwie wysokim stopniu zasady zrównoważonego rozwoju ${ }^{27}$.

Strategia zrównoważonego rozwoju jest podstawą aktów planowania przestrzennego. Na system planowania przestrzennego składają się: na poziomie kraju koncepcja zagospodarowania przestrzennego oraz programy rządowe dotyczące realizacji inwestycji celu publicznego, na poziomie województwa plan zagospodarowania przestrzennego województwa, a na poziomie gminy studium uwarunkowań i kierunków zagospodarowania przestrzennego, oraz miejscowy plan zagospodarowania przestrzennego.

Najwięcej miejsca problematyce zrównoważonego rozwoju poświęca pierwszy z wymienionych dokumentów, a mianowicie Koncepcja przestrzennego zagospodarowania kraju ${ }^{28}$. Przyjęta w dniu 17 listopada 2000 r. przez Sejm RP29 jeszcze pod rządami nieobowiązującej już ustawy z dnia 7 lipca 1994 r. o zagospodarowaniu przestrzennym jest najważniejszym dokumentem określającym zasady polityki państwa $\mathrm{w}$ dziedzinie przestrzennego zagospodarowania kraju w perspektywie najbliższych kilkunastu lat. W latach 2004-2005 w Rządowym Centrum Studiów Strategicznych dokonano aktualizacji Koncepcji przestrzennego zagospodarowania kraju, uwzględniając nowe czynniki ustrojowo-prawne, w szczególności zaś członkostwo Polski w Unii Europejskiej. Nie bez znaczenia dla aktualizacji tego dokumentu były też inne czynniki, takie jak zmieniające się w związku z rozwojem obszarów metropolitarnych warunki przestrzenne. Głównym przesłaniem aktualizacji Koncepcji była zgodność z ideą zrównoważonego rozwoju. Na uwagę zasługuje fakt, że w porównaniu do Koncepcji z 2000 r. zaprzestano posługiwania się innymi niż zrównoważony rozwój określeniami (np. ekorozwoj), nawiązując wyraźnie do definicji z ustawy - Prawo ochrony środowiska. Po raz pierwszy zwrócono też uwagę na możliwość występowania konfliktów przestrzennych i sprzeczności interesów, które wynikają z odmiennych potrzeb i interesów różnych grup społecznych i rzeczywistych lub potencjalnych użytkowników przestrzeni oraz jej walorów. Przyjęto, że w takich sytuacjach nale-

27 Zob. Planowanie i zagospodarowanie przestrzenne w praktyce, red. M. Berdysz, cz. 2, rozdz.1, podrozdz. 1, s. 3 .

28 Obszerną analizę tego dokumentu w kontekście zrównoważonego rozwoju przeprowadził Z. Bukowski, wskazując na występujący w niej chaos pojęciowy, zob. Z. Bukowski, op. cit., s. 536-594 .

MP z 2001 r., Nr 26, poz. 432. 
ży kierować się zasadą dobra wspólnego i prymatu rozwiązań mniej obciążających środowisko przyrodnicze $\mathrm{e}^{30}$.

Dnia 9 października 2006 r. Rada Ministrów podjęła postanowienie o rozpoczęciu przez Ministerstwo Rozwoju Regionalnego prac nad nową Koncepcją przestrzennego zagospodarowania kraju. Pierwszym etapem prac nad nowym dokumentem było sformułowanie Tez i Założeń do Koncepcji przestrzennego zagospodarowania kraju ${ }^{31}$. W rezultacie przeprowadzonych prac merytorycznych został opracowany „Ekspercki Projekt Koncepcji Przestrzennego Zagospodarowania Kraju do roku 2033”. Dokument ten nie jest projektem dokumentu rządowego, lecz ekspercką oceną sytuacji i trendów w zakresie rozwoju przestrzennego w Polsce, i jako taki stanowił będzie podstawę opracowania projektu dokumentu rządowego. Jako główny, nadrzędny cel polityki przestrzennej przyjęto w nim poprawę spójności terytorialnej kraju w wymiarze krajowym i europejskim, przy jednoczesnym wchodzeniu na ścieżkę rozwoju suspensywnego (trwałego i zrównoważonego ekologicznie). Zasady, w oparciu na których powinna być prowadzona polska polityka przestrzenna to - zdaniem autorów projektu - zasada rekompensacji ekologicznej oraz zasada długookresowej racjonalności ekologicznej.

Zrównoważony rozwój jako cel i strategia nowoczesnego gospodarowania przestrzenią powinien znaleźć odzwierciedlenie na poziomie regionalnym i lokalnym. Dokumentem polityki przestrzennej województwa jest plan zagospodarowania przestrzennego województwa, który jest podstawowym narzędziem prowadzenia polityki przestrzennej na poziomie regionu o cechach planu gospodarczego.

Głównym zadaniem tego dokumentu jest określenie przestrzennych uwarunkowań rozwoju oraz kierunków i priorytetów kształtowania środowiska przyrodniczego, kulturowego i zurbanizowanego w ciągu najbliższych kilkunastu lat i jako taki powinien uwzględniać inne dokumenty strategiczne, przede wszystkim

30 Zob. Zaktualizowana koncepcja przestrzennego zagospodarowania kraju, Rządowe Centrum Studiów Strategicznych, Warszawa, październik 2005, druk sejmowy nr 4, Sejm RP V kadencja, Warszawa, 19 października 2005 r., s. 91.

31 W tym celu został powołany Zespół roboczy do opracowania Tez i Założeń do KPZK, w którego skład weszli pracownicy Ministerstwa Rozwoju Regionalnego oraz przedstawiciele resortów, których działalność w sposób znaczący wpływa bezpośrednio na zagospodarowanie przestrzenne kraju. 29 stycznia 2007 r. Zarządzeniem Prezesa Rady Ministrów została powołana Państwowa Rada Gospodarki Przestrzennej (PRGP). Podstawę prawną powołania PRGP stanowi ust. 5 art. 47 ustawy o planowaniu i zagospodarowaniu przestrzennym (Dz.U. z 2003 r. Nr 80, poz. 717): „Prezes Rady Ministrów może powołać Państwową Radę oraz ustalić, w drodze Gospodarki Przestrzennej, jako organ doradczy w sprawie koncepcji przestrzennego zagospodarowania kraju, zarządzenia, regulamin określający zadania, organizację i tryb jej działania”. 
zaś strategię rozwoju województwa oraz koncepcję przestrzennego zagospodarowania kraju.

Dokument ten stanowi oś zagospodarowania przestrzennego województwa i sporządzany jest dla całego obszaru województwa w jego granicach administracyjnych. Cechą charakterystyczną planu zagospodarowania przestrzennego województwa jest to, że jest on sporządzany na czas nieokreślony, choć - w miarę potrzeb rozwojowych województwa - powinien być aktualizowany. W świetle art. 39 pkt $3 \mathrm{w}$ planie zagospodarowania przestrzennego województwa uwzględnia się ustalenia strategii rozwoju województwa oraz określa się w szczególności: podstawowe elementy sieci osadniczej województwa i ich powiązań komunikacyjnych oraz infrastrukturalnych, w tym kierunki powiązań transgranicznych; system obszarów chronionych, w tym obszary ochrony środowiska, przyrody i krajobrazu kulturowego, ochrony uzdrowisk oraz dziedzictwa kulturowego i zabytków oraz dóbr kultury współczesnej; rozmieszczenie inwestycji celu publicznego o znaczeniu ponadlokalnym; obszary problemowe wraz z zasadami ich zagospodarowania oraz obszary metropolitalne; obszary wsparcia; obszary narażone na niebezpieczeństwo powodzi oraz zagrożone ruchami masowymi ziemi; granice terenów zamkniętych i ich stref ochronnych oraz obszary występowania udokumentowanych złóż kopalin. Uwzględnianie tych elementów w zagospodarowaniu przestrzennym województwa jest spójne $z$ ideą zrównoważonego rozwoju. $Z$ jednej strony respektuje się tu potrzeby rozwoju gospodarczego województwa, z drugiej zaś wymagania ochrony środowiska i dóbr kultury. Tak określony zakres planu zagospodarowania przestrzennego województwa stawia przed organami samorządu województwa trudne zadania, polegające na dokonywaniu wyboru optymalnych z punktu widzenia zrównoważonego rozwoju wariantów, przy uwzględnieniu oczekiwań mających często sprzeczne interesy grup społecznych.

Najniższym poziomem planowania przestrzennego jest gmina. Jeśli jednak weźmie się pod uwagę konstytucyjną zasadę pomocniczości i zasadę decentralizacji zadań publicznych, gmina jawi się jako najważniejsza jednostka planowania przestrzennego. Posiada bowiem w tym zakresie uprawnienia, których nie ma żadna inna jednostka samorządu terytorialnego. Stanowi o przeznaczeniu i zasadach zagospodarowania przestrzennego, a jej rozstrzygnięcia mają moc powszechnie obowiązującą ${ }^{32}$ i przez to wiążą właścicieli gruntów i inne podmioty, które na tej podstawie mogą zrekonstruować sferę praw i obowiązków w zakresie dysponowania przestrzenią.

Podstawowym instrumentem sterowania zrównoważonym rozwojem gminy jest studium uwarunkowań i kierunków zagospodarowania przestrzennego (zwane dalej studium). Dokument ten uchwalany jest przez organ stanowiący

32 Z. Niewiadomski, Planowanie przestrzenne. Zarys systemu, Warszawa 2003, s. 85. 
gminy i jest podstawą do opracowania miejscowego planu zagospodarowania przestrzennego. Studium nie posiada charakteru prawa miejscowego, lecz jest wewnętrznym aktem władz danej jednostki ${ }^{33}$. W konsekwencji zobowiązuje on władze samorządowe do realizacji określonej polityki przestrzennej oraz kierunków rozwoju gospodarczego. Należy więc w tym dokumencie wyznaczyć pewne długookresowe cele zrównoważonego rozwoju jednostki samorządu terytorialnego w celu zachowania właściwych proporcji między uwarunkowaniami społecznymi, ekonomicznymi oraz przyrodniczymi na danym obszarze.

Zasada zrównoważonego rozwoju tkwi u podstaw wyznaczania w studium kierunków rozwoju gmin i podstawowych założeń jej polityki przestrzennej. Przez pryzmat tej zasady organy gminy winny prowadzić politykę przestrzenną. Przez studium władze gminy dokonują podstawowych ustaleń, wskazując tereny przeznaczone pod zabudowę, wstępną lokalizację infrastruktury technicznej i komunikacyjnej, obszary rozmieszczenia inwestycji celu publicznego, obszary ochrony środowiska $\mathrm{i}$ jego zasobów $\mathrm{i}$ inne wymienione w art. 10 ust 2 u.p.z.p.

Nie mniej ważną z punktu widzenia realizacji zasady zrównoważonego rozwoju rolę odgrywa miejscowy plan zagospodarowania przestrzennego (zwany dalej planem). Istotnym novum w określeniu stosunku studium do planu jest, że ten ostatni nie może być sprzeczny ze studium (w miejsce poprzednio obowiązującej zasady bezwzględnej zgodności planu ze studium). W dalszym ciągu jednak aktualna jest teza, że zapisy planu nie mogą doprowadzić do modyfikacji kierunków zagospodarowania przewidzianego $\mathrm{w}$ studium lub też tego zagospodarowania wykluczyćc ${ }^{34}$.

Odmienny od studium charakter prawny miejscowego planu zagospodarowania przestrzennego powoduje, że zasada zrównoważonego rozwoju ma konkretny i realny wymiar. Plan jest bowiem aktem prawa miejscowego i jako taki bezpośrednio oddziałuje na sferę prawną uczestników procesu planistycznego (właścicieli nieruchomości, inwestorów). Realizacyjny i bezpośrednio wykonawczy charakter planu powoduje, że gminy z dużą rozwagą powinny realizować swo-

33 Charakter prawny studium uwarunkowań i kierunków zagospodarowania przestrzennego wiernie oddaje wyrok Naczelnego Sądu Administracyjnego z dnia 21 listopada 2000 r. (II S.A. 2437/99): „Studium uwarunkowań i kierunków zagospodarowania przestrzennego gminy nie jest aktem ustanawiającym przepisy gminne [...]. Studium nie ma więc mocy aktu powszechnie obowiązującego. Określa - jako akt planistyczny - jedynie politykę przestrzenną gminy i wiąże wewnętrznie organy gminy w ich planach przy sporządzaniu projektów planów miejscowych. Jako akt kierownictwa wewnętrznego (w stosunkach rada i podporządkowane jej jednostki organizacyjne) określa więc tylko kierunki i sposoby działania jednostek pozostających w systemie organizacyjnym aparatu gminy przy sporządzaniu projektu przyszłego miejscowego planu zagospodarowania przestrzennego. Studium stanowi więc jeden $z$ etapów poprzedzających uchwalanie planu i nie może tym samym, w żadnym przypadku, stanowić podstawy do wydania decyzji”.

34 Wyrok WSA Gdańsk z 2009-04-29, II SA/Gd 563/08 Legalis. 
je władztwo planistyczne ${ }^{35}$. Nie ulega wątpliwości, że równorzędne traktowanie racji społecznych, gospodarczych i środowiskowych powinno być brane pod uwagę zarówno na etapie tworzenia planów, jak i w gospodarowaniu przez gminy przestrzenią na obszarach, dla których nie uchwalono miejscowego planu zagospodarowania przestrzennego (czyli w decyzjach lokalizacyjnych dla inwestycji publicznych i decyzjach o warunkach zabudowy i zagospodarowania terenu dla inwestycji niepublicznych).

\section{KONFLIKTY PRZESTRZENNE NA TLE ZASADY ZRÓWNOWAŻONEGO ROZWOJU}

Gospodarowanie przestrzenią jest obszarem $z$ natury konfliktogennym, uczestnicy procesu planistycznego lub inwestycyjnego mają bowiem często sprzeczne interesy. Konflikt interesów jest pojęciem obecnym w naukach innych niż nauki prawne, np. w naukach społecznych, politycznych i ekonomicznych. W teorii i dogmatyce prawa pojęcie konfliktu interesów występuje jako pewien układ wartości i potrzeb, które wzajemnie się wykluczają. Zdaniem M. Wyrzykowskiego przez konflikt interesów rozumie się „układ skierowanych przeciw sobie zachowań co najmniej dwóch podmiotów dążących do realizacji własnych interesów i napotykających przeciwdziałanie pozostałych uczestników konfliktu”36. W sferze planowania i zagospodarowania przestrzennego konflikt interesów należy postrzegać jednak znacznie szerzej - nie tylko jako konflikt podmiotów indywidualnych, ale również konflikt, w którym obecny jest podmiot publiczny.

Koncepcja planowania i zagospodarowania przestrzennego w polskim systemie prawnym jest dość wyraźnie naznaczona kategorią interesu publicznego rozumianego jako uogólniony cel dążeń i działań, uwzględniających zobiektywizowane potrzeby ogółu społeczeństwa lub lokalnych społeczności (art. 2 pkt 4 u.p.z.p.). Zakreślony w tej definicji kontekst znaczeniowy uprawnia do stwierdzenia, że pojęcie interesu publicznego należy wiązać z filozoficzną koncepcją dobra wspólnego ${ }^{37}$. Wypada zauważyć, że dobro wspólne nie może być identyfikowane

35 Podkreślane jest to wyraźnie w wyroku WSA w Krakowie z 23 czerwca 2008 r. „Mając wyłączną kompetencję do planowania miejscowego, gmina może, pod warunkiem że działa w granicach i na podstawie prawa, samodzielnie kształtować sposób zagospodarowania obszaru podlegającego jej władztwu planistycznemu, jeżeli oczywiście władztwa tego nie nadużywa, a organy państwa, w tym sąd administracyjny, nie moga jej władztwa planistycznego pozbawić”.

36 M. Wyrzykowski, Pojęcie interesu spotecznego w prawie administracyjnym, Warszawa 1986, s. 164.

37 Zob. M. Stahl, Dobro wspólne w prawie administracyjnym, [w:] Nowe problemy badawcze w teorii prawa administracyjnego, red. J. Boć i A. Chajbowicz, Kolonia Limited 2009, s. 47 i cytowana tam literatura, zob. też R. Sowiński, Interes publiczny - dobro wspólne. Wartości uniwersalne jako 
z sumą interesów jednostkowych ${ }^{38}$. Takie rozumienie interesu publicznego prowadziłoby bowiem do błędnego wniosku, że spełnienie oczekiwań wszystkich indywidualnych użytkowników przestrzeni leży w interesie publicznym. Należy zatem przyjąć, że potrzeby interesu publicznego w planowaniu przestrzennym winny zmierzać do zaspokojenia korzyści w wymiarze ogólnospołecznym (w gminie - w wymiarze lokalnym), przy jednoczesnym uwzględnieniu racjonalnych oczekiwań możliwie największej liczby jednostek. W poszukiwaniu kompromisu pomiędzy interesami podmiotów występujących w procesie planowania i zagospodarowania przestrzennego pomocnym narzędziem jest zapewnienie udziału społecznego, szczególnie w gminach, gdzie interes publiczny ma często bardzo konkretny wymiar, a jego realizacja powinna uwzględniać interes partykularny.

Konflikt interesów może występować w kilku płaszczyznach. Pierwszą płaszczyzną jest konflikt na linii interes indywidualny-interes indywidualny. Powstaje on wówczas, gdy dwa podmioty mające prawo do dysponowania nieruchomością na cele budowlane mają odmienną koncepcję urządzenia wspólnego wycinka przestrzeni (np. w przypadku współwłasności).

Drugi, znacznie częściej występujący rodzaj konfliktu to konflikt na linii interes indywidualny-interes publiczny. Ta sama inwestycja może rodzić inne reperkusje po stronie właściciela (lub podmiotu posiadającego tytuł prawny do nieruchomości), inne zaś po stronie organów administracji uczestniczących w procesie planistycznym, które z założenia są strażnikami interesu publicznego. W konflikt ten włączają się często nie tylko aktualni, ale i przyszli inwestorzy zainteresowani korzystnym dla nich zagospodarowaniem terenu. Uczestnikami tego rodzaju konfliktu są często organizacje społeczne (głównie ekologiczne), które uzurpują sobie prawo do roli, która tradycyjnie przypada organowi administracji publicznej, czyli strażnika interesu publicznego, występując często w interesie ochrony środowiska.

W praktyce zdarza się, że jeden podmiot podlega ochronie prawnej ze względu na oba rodzaje interesów. Mieszkaniec gminy mający swój interes indywidualny w zagospodarowaniu przestrzennym jest jednocześnie podmiotem ochrony interesu publicznego, przestrzeń bowiem (nawiązując do filozoficznej koncepcji) jest dobrem wspólnym wszystkich mieszkańców gminy. $Z$ drugiej strony każdy ma prawo, w granicach określonych ustawą, do zagospodarowania terenu, do którego ma tytuł prawny, zgodnie $\mathrm{z}$ warunkami ustalonymi w miejscowym planie

kategorie ksztattujace pojęcie administracji, [w:] Prawo do dobrej administracji. Materiaty ze Zjazdu Katedr Prawa i Postępowania Administracyjnego, red. Z. Niewiadomski, Z. Cieślak, Warszawa 2003, s. $564 \mathrm{in}$.

${ }_{38}$ Ten kierunek rozumienia istoty interesu publicznego dominuje w nauce prawa administracyjnego, zob. J. S. Langrod, Instytucje prawa administracyjnego, Zarys części ogólnej, Kraków 2003 (reprint), s. 33; M. Wyrzykowski, op. cit., s. 36. 
zagospodarowania przestrzennego albo decyzji o warunkach zabudowy i zagospodarowania terenu, jeżeli nie narusza to chronionego prawem interesu publicznego oraz osób trzecich oraz do ochrony własnego interesu prawnego przy zagospodarowaniu terenów należących do innych osób lub jednostek organizacyjnych. Każda ingerencja w sposób wykonywania prawa własności musi zatem mieścić się w granicach wyznaczonych interesem publicznym ${ }^{39}$.

Trzeci rodzaj konfliktu to konflikt w obrębie samego interesu publicznego. Może mieć on charakter podmiotowy, kiedy interes państwowy lub regionalny nie znajduje pokrycia na terenie gminy. Kolizje interesów lokalnych z ponadlokalnymi mogą występować zarówno na etapie określania zadań do wykonania w różnym czasie, przy określaniu ważności tych zadań, uwarunkowań zewnętrznych i wewnętrznych ich realizacji, jak również na etapie uchwalania planów ${ }^{40}$. Konflikt w obrębie interesu publicznego może mieć również charakter przedmiotowy, kiedy w grę wchodzi konflikt zadań publicznych, np. ochrona środowiska a rozbudowa infrastruktury drogowej. Celem planowania przestrzennego jest realizowanie potrzeb ogółu społeczeństwa lub lokalnych społeczności, jednak $\mathrm{z}$ istoty demokratycznego państwa prawnego wynika obowiązek wyważenia tych interesów ${ }^{41}$.

W praktycznej realizacji zasady zrównoważonego rozwoju ważne jest właściwe wykorzystanie walorów ekonomicznych przestrzeni. Wymaga to dokonywania przez podmioty publiczne czynności polegających na wartościowaniu terenów pod względem ich przydatności do określonych celów. Gospodarkę przestrzenną należy prowadzić możliwie efektywnie pod względem ekonomicznym, czyli na tych terenach, gdzie jest to ekonomicznie uzasadnione, a jednocześnie nie wiąże się z uciążliwościami dla osób trzecich lub innych wartości (np. ochrony środowiska lub zabytków), należy umożliwić inwestowanie.

\footnotetext{
39 Wyrok WSA Warszawa z 2009-12-07, IV SA/Wa 1562/09, Legalis.

40 E. Malisiewicz, Istota i funkcje planowania przestrzennego w gospodarce rynkowej, [w:] Prawo - administracja - gospodarka w procesie transformacji ustrojowej Rzeczypospolitej Polskiej, red. J. Buczkowski, J. Posłuszny, Przemyśl 2001, s. 544.

41 Pogląd taki wyraził Sąd Najwyższy w wyroku z dnia 18 listopada 1993 r. (III ARN 49/93; OSN 1994/9/181): „W państwie prawa nie ma miejsca dla mechanicznie i sztywno pojmowanej zasady nadrzędności interesu ogólnego nad interesem indywidualnym. Oznacza to, że w każdym przypadku działający organ ma obowiązek wskazać, o jaki interes ogólny (publiczny) chodzi i udowodnić, iż jest on na tyle ważny i znaczący, że bezwzględnie wymaga ograniczenia uprawnień indywidualnych obywateli”. Zob. też Ustawa o planowaniu zagospodarowaniu przestrzennym. Komentarz, red. Z. Niewiadomski, 2 wyd. Wyd. C.H. Beck, Warszawa 2006, s. 6-7.
} 


\section{ZAKOŃCZENIE}

Zasada zrównoważonego rozwoju jest jedną z zasad, która z woli ustawodawcy legła u podstaw polskiego systemu planowania przestrzennego. Przez jej pryzmat należy odczytywać sens innych zasad planowania i zagospodarowania przestrzennego, np. zasady uwzględniania interesu publicznego czy zasady uwzględniania ochrony środowiska i innych wartości. Stanowi ona wytyczą interpretacyjną przepisów dotyczących nowoczesnego gospodarowania przestrzenią oraz wszelkich aspektów stosowania tych przepisów w skali państwa, województwa i gminy. Praktyczna realizacja zrównoważonego wykorzystania przestrzeni, czyli takiego korzystania, które w równym stopniu respektuje względy gospodarcze, środowiskowe i społeczne, spoczywa na organach administracji publicznej. $\mathrm{Na}$ tle realizacji tej zasady mogą jednak powstawać konflikty przestrzenne, użytkownicy przestrzeni mają bowiem nierzadko sprzeczne interesy. Sprzeczność ta może dotyczyć konfliktów interesów prywatnych z publicznymi, ale może też wystąpić tylko w obrębie interesu publicznego, np. potrzeba uwzględnienia ochrony środowiska przy realizacji inwestycji drogowej. Kolizja interesów może występować między interesem lokalnym a regionalnym lub krajowym, między interesem publicznym a prywatnym, jak również między interesem podmiotów indywidualnych, których intencje wobec tego samego wycinka przestrzeni różnią się.

Niezależnie jednak od źródła konfliktu ciężar wyważenia interesów różnych grup społecznych spoczywać będzie na organach władzy publicznej. Istotne jest, by nie straciły one $\mathrm{z}$ pola widzenia zasady zrównoważonego rozwoju, starając się w miarę możliwości uwzględniać zarówno walory ekonomiczne przestrzeni, ochronę środowiska i innych wartości, jak i oczekiwania społeczne, uruchomione nierzadko potrzebą ochrony własnego interesu prawnego. Wiele społecznych konfliktów wynika z uzasadnionej prawnie potrzeby ochrony prawa własności, ale część występuje na linii gospodarka-środowisko, czego namacalnym dowodem był konflikt w Dolinie Rospudy.

\section{BIBLIOGRAFIA}

Alberski R., Lisicka A., Sommer J., Polityka ochrony środowiska, Acta Universitatis Wratislaviensis, nr 2406, Wrocław 2002.

Boć J., Ochrona środowiska w postanowieniach Konstytucji Rzeczypospolitej Polskiej, [w:] Problemy prawa angielskiego i europejskiego oraz reformy w Europie Srodkowej (Polska, $W_{e}$ gry), red. K. Nowacki, Acta Universistatis Wratislaviensis, nr 2244, Prawo CCLXXII, Wrocław 2000, s. 190.

Boć J., Nowacki K., Samborska-Boć E., Ochrona środowiska, Kolonia Limited, Wrocław 2000. 
Budnikowski A., Dostosowanie polityki ochrony środowiska w Polsce do wymogów Unii Europejskiej, SGH, Warszawa 1997.

Bukowski Z., Zrównoważony rozwój w systemie prawa, Toruń 2009.

Ciechanowicz J., Międzynarodowe prawo ochrony środowiska, Wydawnictwa Prawnicze PWN, Warszawa 1999.

A. Chmielak, Problemy badawcze teorii trwatego i zrównoważonego rozwoju, „Ekonomia i Środowisko"1998, nr 2.

Grabowska G., Cztowiek i środowisko w prawie międzynarodowym, „Państwo i Prawo” 1996, z. 1.

Grabowska G., Europejskie prawo środowiska, Warszawa 2001.

Gruszecki K., Ochrona prawna środowiska w Unii Europejskiej-źródta prawa europejskiego, „Aura” 1999, nr 1.

Kenig-Witkowska M.M., Koncepcja „sustainable development” w prawie międzynarodowym, „Państwo i Prawo” 1988, z. 8.

Kozłowski S., Droga do ekorozwoju, Warszawa 1994.

Leoński Z., Szewczyk M., Zasady prawa budowlanego i zagospodarowania przestrzennego, Bydgoszcz-Poznań 2002.

Langrod J.S., Instytucje prawa administracyjnego, Zarys części ogólnej, Kraków 2003 (reprint).

Machowski J., Ochrona środowiska. Prawo i zrównoważony rozwój, Warszawa 2003.

Malisiewicz E., Istota i funkcje planowania przestrzennego w gospodarce rynkowej, [w:] Prawo - administracja - gospodarka w procesie transformacji ustrojowej Rzeczypospolitej Polskiej, red. J. Buczkowski, J. Posłuszny, Przemyśl 2001.

Niewiadomski Z., Planowanie przestrzenne. Zarys systemu, Warszawa 2003.

Nowe regulacje prawne ochrony środowiska w Polsce dostosowanie do wymagań Unii Europejskiej, red. J. Jendrośka, Centrum Prawa Ekologicznego, Wrocław 2001.

Paczuski R., Prawo ochrony środowiska, Bydgoszcz 2000.

Paczuski R., Zaczęto się w ONZ. Zrównoważony rozwój zadaniem wspótczesnego państwarola polityki i prawa w jego realizacji, „Ekoprofit” 1998, nr 7/8.

Poskrobko B., Teoretyczne aspekty ekorozwoju, „Ekonomia i Środowisko” 1997, nr 1.

Poskrobko B., Spoteczne czynniki ochrony środowiska, [w:] Ochrona środowiska. Problemy spoteczne, ekonomiczne i prawne, Warszawa 1998.

Pyć D., Zasada zrównoważonego rozwoju w prawie międzynarodowym. Materiały $\mathrm{z}$ konferencji pt. „Prawo międzynarodowe w dobie transformacji społeczności międzynarodowej”, Kraków 21-22 września 2000 r.

Równy K., Ekologiczne warunki cztonkostwa w Unii Europejskiej i zbliżanie sie do nich w Polsce, cz. I: Podstawy wymogów ekologicznych w prawie wspólnotowym, „Prawo i Środowisko" 1997, nr 3.

Równy K., Koncepcja zrównoważonego rozwoju w prawie wspólnotowym i polskiej rzeczywistości, „Przegląd Prawa Europejskiego” 2000, nr 2.

Sitek M., „Sustainable development” - ciagty czy zrównoważony rozwój?, artykuł polemiczny, „Państwo i Prawo” 1999, z. 2.

Skubiszewski S., Uchwaty prawotwórcze organizacji międzynarodowych. Przegląd zagadnienia i analiza wstępna, Poznań 1965. 
Sommer J., Prawo ochrony środowiska w Polsce, Wrocław 1993.

Sommer J. w: W. Radecki, J. Sommer, W. Szostek, Ustawa o zagospodarowaniu przestrzennym oraz wybrane przepisy wykonawcze. Komentarz, Wrocław 1995.

Sowiński R., Interes publiczny - dobro wspólne. Wartości uniwersalne jako kategorie ksztattujace pojecie administracji, [w:] Prawo do dobrej administracji. Materiały ze Zjazdu Katedr prawa i Postępowania Administracyjnego, red. Z. Niewiadomski, Z. Cieślak, Warszawa 2003, s. 564 i nast.

Stahl M., Dobro wspólne w prawie administracyjnym [w:] Nowe problemy badawcze w teorii prawa administracyjnego, red. J. Boć i A. Chajbowicz, Kolonia Limited 2009.

Ustawa o planowaniu zagospodarowaniu przestrzennym. Komentarz, red.Z. Niewiadomski, 2 wyd., Wyd. C.H. Beck, Warszawa 2006.

Wolfke K., Zagadnienie źródet w międzynarodowym prawie środowiska, Acta Universitatis Brunensis - Iuridica nr 29, s. 107-109.

Wyrzykowski M., Pojecie interesu spotecznego w prawie administracyjnym, Warszawa 1986.

\title{
SUSTAINABLE DEVELOPMENT AS A STRATEGY TO DEFINE MODERN LAND DEVELOPMENT PLANNING (LEGAL ASPECTS)
}

\author{
SUMMARY
}

The subject of the discussion in the article is the principle of sustainable development in the law of planning and land development planning, shown on the background of the development of this policy or how it is defined in the legal and economic sciences. It lies at the root of all activities of state and local government, both in terms of spatial policymaking as well as on the establishment of rules to allocate land for specific purposes, their management and development . Sustainable development is presented as objective and the strategy of modern space management at national, regional and local levels. On each of these levels of planning, acts are issued in which the sustainable use of space, which respects the values of both its economic and environmental requirements is a more important value. From the normative point of view, sustainable development is one of the general principles of planning and the land development plan. Planning and land development planning are also shown as an area particularly susceptible to the possibility of spatial conflicts. An important role in resolving these conflicts falls to public authorities , especially the authorities of municipalities, where the conflict is of a concrete nature to do with the spatial dimension. 